\title{
Morphological and agronomic characterization of tomato under field conditions
}

Qasid Ali ${ }^{1,2 *}$, Mustafa Erkan ${ }^{1}$ and Ibadullah $\mathrm{Jan}^{2}$

1. Department of Horticulture, Akdeniz University, 07059 Antalya-Turkey

2. Department of Horticulture, University of Swabi, Swabi-Pakistan

*Corresponding author's email: ali_khan4540@yahoo.com

Citation

Qasid Ali, Mustafa Erkan and Ibadullah Jan. Morphological and agronomic characterization of tomato under field conditions. Pure and Applied Biology. Vol. 6, Issue 3, pp1021-1029. http://dx.doi.org/10.19045/bspab.2017.600108

Received: 06/04/2017

Revised: $15 / 08 / 2017$

Accepted: 24/08/2017

Online First: 28/08/2017

\section{Abstract}

This experiment was conducted at Plant Genetic Resources Institute, National Agricultural Research Centre, Islamabad. A total of 156 germplasm accessions of tomatoes of local and exotic origin from the National Genebank of Pakistan at PGRI were used. Agro-morphological traits including 14 quantitative traits were studied. Tomato accessions were grown under a controlled environment and two-week-old seedlings were then transferred to trays which were later on transplanted in the field at 3-4 leaf stage. The accessions were grown in the field with a plant to plant distance of $50 \mathrm{~cm}$ and row to row distance of 75 . Frequency distribution for all agro-morphological characteristics was studied. Variation was observed for all the parameters studied. Maximum yield per plant was found in accession 17863 while maximum fruit size was observed in accessions LA-3346, Dny-evf-Riograndea (a) and LA-0146 (a). Descriptive statistics showed high variation in case of fruit length, fruit width, pedicel length, total number of inflorescence, and yield per plant which indicates that these characteristics can be improved using the present tomato germplasm. Correlation analysis was performed to know about the morphological characteristics positively correlated with economically important traits. Cluster analysis and dendrogram construction shows the genetic diversity in the germplasm which indicates the usefulness of germplasm for tomato hybridization and breeding.

Key words: Germplasm, agro-morphological traits, seedlings, tomato, yield

\section{Introduction}

The tomato (Lycopersicon esculentum Mill., syn: Solanum lycopersicum) is an edible fruit belonging to family Solanaceae, originated from South America [1]. Tomatoes are classified as tropical crop and can tolerate high temperatures but they are sensitive to frost at each growth stage [2]. Increase of tomato yield has been observed with temperature ranges up to $32^{\circ} \mathrm{C}$ in month from April to June, with a decline at warmer temperatures [3]. It is used as a vegetable in variety of ways. It is perennial in nature but it is grown as annual vegetable. The plant vines are typically pubescent, covered with fine short hairs. These hairs facilitate the process of climbing, which turns into roots where the plant is in contact with the ground and moisture, especially if the connection of vines is damaged or cut off [4]. Tomato fruit like grapes, bananas, and dates are classified as berries because 
many seeds are enclosed in the thick pericarp. When the ovary is converted in fruit, the ovary wall develops into flesh of the fruit [5]. Fruit contains hollow spaces full of seeds and moisture, called locules/cavities that vary from two up to ten or more. Numbers of locules influence the fruit size and shape which is controlled by several quantitative trait loci [6]. Tomatoes are generally classified as determinate and indeterminate. Determinate or bushy type tomato plant bears fruit within a short period of time and top off at a specific height. Such types of tomatoes are generally preferred by the commercial growers who wish to harvest whole field at once or in limited period of time. Indeterminate types develop into vines that never top off and continue producing until killed by frost. Such types are preferred by home growers and local-market farmers who want ripe fruit throughout the season [7]. Consumers assess the quality of tomato fruits by three factors primarily those are physical appearance (colour, size, shape, defects, and decay), firmness, and taste. In breeding of tomato, substantial efforts have been made to improve yield, fruit size, appearance of fruit (without defects and appealing colour), disease resistant, and more recently firmness of fruit and shelf life to allow export or import for longer distances [8]. Characteristics like flavour, appearance, colour, and handling are important for fresh market industry while viscosity and solids are the key factors considered for processing industry. The agronomic characteristics have been the centre of concentration in breeding programs which enabled the industry for genuine production of tomato under different climatic and environmental conditions [9]. Characterization is an important method for the identification of a specific genotype. We can easily differentiate the genotypes by physical observing its characters (morphological characterization). Previously it was reported that systemic characterization of African eggplant varieties or lines using morphological traits is needed to biofuel breeder's efforts in the species [10]. The objective of this study was to characterize tomato germplasm through morphological and agronomic traits. This study will be helpful for development of variety, hybrid seed production, and identification of desirable genotypes from germplasm.

\section{Materials and methods}

The present experiment was carried out at PGRI, National Agricultural Research Centre, Islamabad in 2013. The trial consisted of 156 accessions of tomatoes. The seeds of these accessions were obtained from PGRI, NARC Islamabad. The seeds of these accessions were initially grown under controlled conditions. The germinated seedlings were transferred into trays, and then to the field at 3-4 leaf stage seedlings.

Six beds were prepared with plant to plant distance of $50 \mathrm{~cm}$ and row to row distance of $75 \mathrm{~cm}$ using randomized complete block design (RCBD). Three plants of each accession were grown in a row. Standard crop management practices were followed throughout crop growing period.

Data for the following quantitative parameters few (3) and many (7) numbers of leaves preceding 1st inflorescence (NLPI), petal length (PL), sepal length (SL), stamen length (StL), fruit size (FS) at maturity 1) very small $(<3 \mathrm{~cm}) 2)$ small $(3-5 \mathrm{~cm}) 3)$ intermediate $(5.1-8 \mathrm{~cm}) 4)$ large $(8.1-10$ $\mathrm{cm}) 5)$ very large $(>10 \mathrm{~cm})$, fruit length $(\mathrm{FL})$ recorded from stem-end to blossom-end to one decimal place at maturity. Fruit width (FW) was recorded at the largest diameter of cross-sectioned fruits to one decimal place at maturity. Pedicel length (Pdl) was measured from peduncle to calyx. Pericarp thickness (PT) was measured from an equatorial section of the fruits. Number of locules (NL), number of inflorescences (NI), 
number of flowers per inflorescence (NFI), number of fruit set per inflorescence (NFSI), and yield per plant (YP), i.e., weight of fruits per plant was recorded.

\section{Data analysis}

Data analysis was conducted using Microsoft Excel 2010 for frequency distribution, descriptive statistics, and correlation analysis. Statistica software was used for cluster analysis and dendrogram construction.

\section{Results and discussion}

The current study describes characterization of tomato genotypes on the basis of quantitative characteristics. The information generated in this study will be useful for better crop improvement strategies in tomato.

\section{Frequency distribution}

\section{Number of leaves preceding} inflorescence

Data for few leaves preceding inflorescence and many leaves preceding inflorescence were recorded. Ninety of genotypes have few leaves preceding inflorescence while the remaining had many leaves preceding inflorescence.

\section{Petal length (mm)}

Maximum petal length15 (mm) was recorded on five genotypes, i.e., LA-3214, LA-3316, Dny-evf-Riograndea (a), 10.(216N02102wala), Lo-0560 while minimum petal length $3(\mathrm{~mm})$ was recorded on TLB-111 genotype.

\section{Sepal length $(\mathrm{mm})$}

Highest sepal length $22(\mathrm{~mm})$ was recorded on LA-2070(b) and least sepal length 4 (mm) was recorded on TLB-111 genotypes.

\section{Stamen length $(\mathrm{mm})$}

Maximum stamen length 11 (mm) was observed on two genotypes, i.e., LA-3346 and LA-3316 while minimum stamen length 3 (mm) was observed on five genotypes, i.e., CN-74, CLN22641, 19904(a), TLB-111, BGR-19906(b).

\section{Fruit size (cm)}

Thirty three genotypes have very small fruit size, sixty four genotypes were observed to have small fruit size, forty three genotypes have intermediate fruit size, and thirteen genotypes were recorded to have large fruit size while three genotypes, i.e., LA-3346, Dny-evf-Riograndea (a), LA-0146(a) were having very large fruit size.

\section{Fruit length ( $\mathrm{mm})$}

Maximum fruit length $67.2 \mathrm{~mm}$ was observed in LA-3346 while minimum fruit length $1.43 \mathrm{~mm}$ was observed in $\mathrm{CN}-100$ (b).

\section{Fruit width (mm)}

Highest fruit width $64.6 \mathrm{~mm}$ was observed on genotype Pehohara while lowest fruit width $1.13 \mathrm{~mm}$ was recorded on LA3320(b).

\section{Pedicel length ( $\mathrm{mm})$}

Maximum pedicel length $40 \mathrm{~mm}$ was recorded on accession 8 while minimum pedicel length $5 \mathrm{~mm}$ was recorded on four accessions, i.e., Lo-2017 (a), Feston, CLN1558A (a), LA-0401 (b).

\section{Pericarp thickness (mm)}

Maximum pericarp thickness of $7.2 \mathrm{~mm}$ was recorded on LA-3346 while minimum pericarp thickness of $0.47 \mathrm{~mm}$ was observed on Tom-2.

\section{Number of locules}

Seven locules were recorded on three accessions that are 9-2(3), Lo-2663, Lo2649 while two locules were recorded on seventy four accessions.

\section{Number of inflorescences}

Maximum number of inflorescence forty five was recorded on 17904 at the main stem while minimum one inflorescence on main stem was recorded on Lo-0981.

\section{Number of flowers per inflorescence}

Highest numbers of flowers eight were observed on accession 19887 while lowest number of flowers two was observed on thirty seven accessions. 


\section{Number of fruit set per inflorescence} Most number of fruit set per inflorescence three was observed on seven genotypes while one fruit set per inflorescence was observed on one hundred and fourteen genotypes.

\section{Yield per plant (g)}

Maximum yield $354.4 \mathrm{~g}$ was recorded on genotype 17863 while minimum yield of 4.8 $\mathrm{g}$ was recorded on Tom-2 genotype.

Frequency distribution showed that there is significant variation in the germplasm for agro-morphological characteristics. Superior germplasm accessions can be selected on the basis of desirable characteristics for tomato improvement.

\section{Descriptive statistics}

Description of quantitative traits is given in Table 1. Fruit length, fruit width, pedicel length, total number of inflorescence, and yield per plant show high variance which indicate that these characteristics have more chances to be improved using the tomato germplasm evaluated during the experiment. Number of leaves preceding inflorescence, sepal length, petal length, stamen length, fruit size, pericarp thickness, number of locules, number of flowers per inflorescence, and fruit set per inflorescence has less chance to be improved due to low variance in the germplasm.

Table 1. Descriptive statistics for quantitative characteristics in $\mathbf{1 5 6}$ accessions of tomato

\begin{tabular}{|l|l|l|l|l|l|}
\hline Characteristics & Mean \pm SE & SD & Variance & $\begin{array}{l}\text { Range } \\
\text { Minimum }\end{array}$ & $\begin{array}{l}\text { Range } \\
\text { Maximum }\end{array}$ \\
\hline $\begin{array}{l}\text { Number of leaves } \\
\text { preceding inflorescence }\end{array}$ & $4.595 \pm 0.154$ & 1.965 & 3.860 & 3 & 7 \\
\hline Sepal length (mm) & $10.050 \pm 0.256$ & 3.253 & 10.585 & 4 & 22 \\
\hline Petal length (mm) & $9.230 \pm 0.192$ & 2.437 & 5.941 & 3 & 15 \\
\hline Stamen length (mm) & $6.366 \pm 0.113$ & 1.439 & 2.071 & 3 & 11 \\
\hline Fruit size (cm) & $2.270 \pm 0.075$ & 0.956 & 0.914 & 1 & 5 \\
\hline Fruit length (mm) & $26.124 \pm 0.910$ & 11.618 & 134.968 & 1.43 & 67.2 \\
\hline Fruit width (mm) & $25.366 \pm 0.774$ & 9.887 & 97.744 & 1.13 & 64.6 \\
\hline Pedicel length (mm) & $14.860 \pm 0.586$ & 6.653 & 44.262 & 5 & 40 \\
\hline Pericarp thickness (mm) & $2.432 \pm 0.085$ & 1.086 & 1.180 & 0.47 & 7.2 \\
\hline No of locules & $2.920 \pm 0.088$ & 1.122 & 1.259 & 2 & 7 \\
\hline $\begin{array}{l}\text { Total number of } \\
\text { inflorescence }\end{array}$ & $9.834 \pm 0.587$ & 7.495 & 56.176 & 1 & 45 \\
\hline $\begin{array}{l}\text { Number of flowers } \\
\text { per inflorescence }\end{array}$ & $3.346 \pm 0.087$ & 1.111 & 1.234 & 2 & 8 \\
\hline Fruit set per inflorescence & $1.313 \pm 0.043$ & 0.550 & 0.303 & 1 & 3 \\
\hline Yield per plant (g) & $45.945 \pm 4.079$ & 52.076 & 2711.930 & 4.73 & 354.4 \\
\hline
\end{tabular}

\section{Correlation analysis}

Correlation analysis of quantitative traits is given in Table 2. Number of leaves preceding inflorescence (NLPI) revealed a significant and positive correlation with PL, FW and PT. According to [11] factors that increase the total amount of assimilates in the plant (e.g. higher light intensity, lower temperature) as well as those that increase the competitive potential of the apex (e.g. lower temperature, certain plant growth regulators) decrease the NLPI. SL showed significant and positive correlation with PL, StL, FS, FL, FW, PT and NL. [12] observed the similar positive correlation between sepal and petal length. PL is significantly 
positively correlated with StL, FS, FL, FW, PT and NL. According to [13] petal length varied significantly with corolla width and calyx length. It is one of the three characteristics that can influence the pollinator attraction and efficiency of pollen transfer. Stamen lengths had a significant and positive correlation with FS, FL, FW, PdL, PT, NL. FS is significant and correlated positively to FL, FW, PdL, PT, NL and YP. It is a direct relationship between fruit size and yield per plant found by Ara et al. [14]. FL is significant and has positive correlation with FW, PdL, PT, NL and YP. [15] reported that fruit length is one of the factors which directly affect the yield as we recorded in our research. FW had a significant and positive correlation with PdL, PT, NL and YP. [16] established the similar relation between fruit width and number of locules. PdL varied significantly and correlated positively with PT, NL and NFI. PT is significant and has positive correlation with NL. Pericarp thickness did not have any impact on the yield per plant in our study which was in contradiction with the positive affect observed in experiment of [16]. NL varied significantly and had positive correlation with yield per plant. No significant effect was found between number of locules and fruit width in our experiment which was in contrast with the result obtained by Souza et al. [16]. NI is significant and has positive correlation with
NFI and NFSI. These results were in agreement with [16]. NFI varied significantly and had positive correlation with NFSI and YP. [17] found the direct impact between number of flowers per inflorescence and fruit set per inflorescence. NFSI is significant and correlated positively with YP; similar observation was found by Nagariya et al. [18]. The negative values show negative correlation among each other.

\section{Cluster analysis of quantitative morphological and agronomic characteristics}

At linkage distance of 6 , twelve clusters were formed (Figure 1). Cluster-1 includes seven genotypes. Cluster-2 includes LA2285, Dny-evf-Riograndea (a), and LA3346. Cluster-3 includes LA-2070(b), Lo0560, LA-0126, La-1021, LA-3316. Cluster4 includes 19296, CN-302, CN-85, 1921(a), Lo-1936. Cluster-5 and Cluster-6 includes six genotypes. Cluster-7 includes eight genotypes. Cluster-8 includes 17867(a), LA0146(a), and Riograndea early. Cluster-9 includes twelve genotypes. Cluster-10 includes six genotypes. Cluster-11 includes 19887, CLN-20260, 17906, 19893, LA2081. Cluster-12 includes LA-2399(a), LA1969(a), 19900, 17860, FLA-496-11-61-0-2. The genetic diversity shown by cluster analysis indicates the usefulness of germplasm for tomato hybridization and breeding. 
1 Table 2. Correlation for quantitative parameters

\begin{tabular}{|c|c|c|c|c|c|c|c|c|c|c|c|c|c|}
\hline & NLPI & $\begin{array}{l}\text { Sepal } \\
\text { length } \\
(\mathrm{mm})\end{array}$ & $\begin{array}{l}\text { Petal } \\
\text { length } \\
(\mathrm{mm}) \\
\end{array}$ & $\begin{array}{l}\text { Stamen } \\
\text { length } \\
(\mathrm{mm}) \\
\end{array}$ & \begin{tabular}{|l|} 
Fruit \\
size \\
$(\mathbf{c m})$ \\
\end{tabular} & $\begin{array}{l}\text { Fruit } \\
\text { length } \\
(\mathrm{mm}) \\
\end{array}$ & $\begin{array}{l}\text { Fruit } \\
\text { width } \\
\text { (mm) } \\
\end{array}$ & $\begin{array}{l}\text { Ped } \\
\text { length } \\
(\mathrm{mm}) \\
\end{array}$ & $\begin{array}{l}\text { Pericarp } \\
\text { thickness } \\
(\mathbf{m m})\end{array}$ & $\begin{array}{l}\text { No of } \\
\text { locules }\end{array}$ & $\begin{array}{l}\text { Total } \\
\text { no of } \\
\text { Inf } \\
\end{array}$ & $\begin{array}{l}\text { Flowers } \\
\text { per inf }\end{array}$ & $\begin{array}{l}\text { Fruit } \\
\text { set per } \\
\text { Inf } \\
\end{array}$ \\
\hline Sepal length & 0.104 & & & & & & & & & & & & \\
\hline Petal length & $0.120 *$ & $0.619 *$ & & & & & & & & & & & \\
\hline Stamen length & 0.063 & $0.409 *$ & $0.701 *$ & & & & & & & & & & \\
\hline Fruit Size & 0.085 & $0.157 *$ & $0.128 *$ & $0.245^{*}$ & & & & & & & & & \\
\hline Fruit length & 0.080 & $0.147 *$ & $0.127 *$ & $0.205^{*}$ & $0.791 *$ & & & & & & & & \\
\hline Fruit Width & $0.143 *$ & $0.181 *$ & $0.190 *$ & $0.301 *$ & $0.736^{*}$ & $0.731 *$ & & & & & & & \\
\hline Pedicel length & 0.058 & $0.138 *$ & 0.077 & $0.115^{*}$ & $0.171 *$ & $0.271 *$ & $0.180 *$ & & & & & & \\
\hline Pericarp thickness & $0.133^{*}$ & $0.199 *$ & $0.134^{*}$ & $0.145^{*}$ & $0.584 *$ & $0.699 *$ & $0.535^{*}$ & $0.152 *$ & & & & & \\
\hline No of locules & 0.080 & $0.127 *$ & $0.165 *$ & $0.148 *$ & $0.313 *$ & $0.241 *$ & $0.495 *$ & $0.252 *$ & $0.144 *$ & & & & \\
\hline Total No of Inf & 0.001 & -0.191 & -0.046 & -0.007 & -0.102 & -0.079 & -0.061 & -0.036 & -0.128 & -0.034 & & & \\
\hline $\begin{array}{l}\text { No of flowers } \\
\text { per Inf }\end{array}$ & -0.051 & -0.139 & -0.210 & -0.162 & 0.042 & $0.135^{*}$ & 0.066 & $0.233 *$ & 0.077 & 0.029 & $0.170^{*}$ & & \\
\hline Fruit set per inf & -0.099 & -0.270 & -0.184 & -0.210 & -0.079 & -0.118 & 0.027 & -0.049 & -0.125 & 0.021 & $0.219 *$ & $0.251 *$ & \\
\hline Yield per plant & -0.054 & -0.121 & -0.023 & -0.42 & $0.234 *$ & $0.168 *$ & $0.283^{*}$ & 0.028 & 0.059 & $0.122 *$ & 0.101 & $0.147 *$ & $0.359 *$ \\
\hline
\end{tabular}

2 Level of Significance $=5 \%$ 


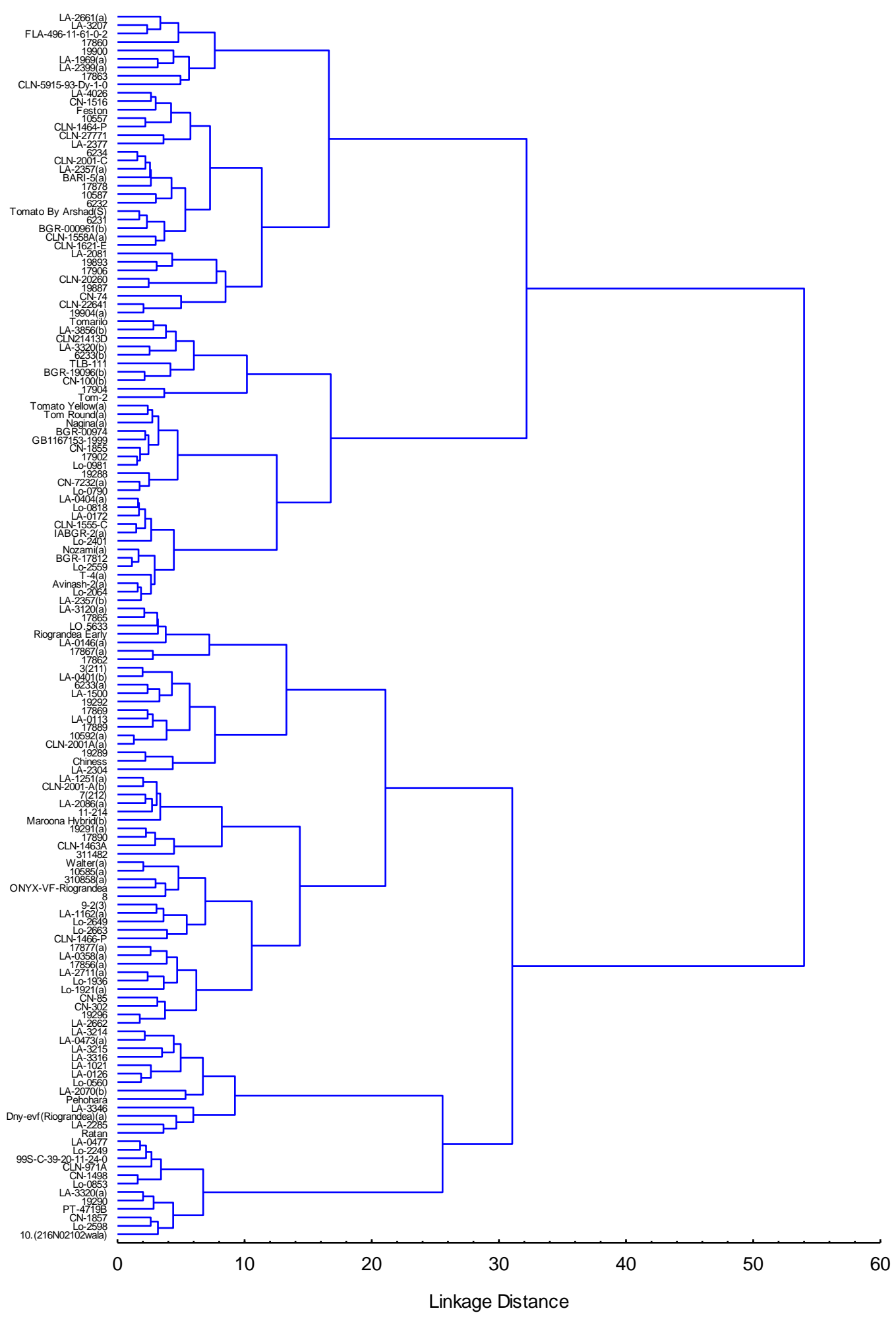

Figure 1. Cluster analysis of 156 tomato germplasm accessions for 14 morphological and agronomic characteristics using Ward's method 


\section{Conclusion}

On the basis of positive correlation of fruit size, fruit length, fruit width, number of locules, flowers per inflorescence and fruit set per inflorescence with yield and fruit size with sepal length, petal length, stamen length, fruit length, fruit width, pedicel length, pericarp thickness, number of locules and yield per plant, these characters can be used for yield improvement of tomato. Variations found among the genotypes on the basis of morphological and agronomical characteristics can be used by the tomato breeders in different hybridization programs for the crop improvement.

\section{Authors' contributions}

Conceived and designed the experiments: Q Ali, Performed the Experiments: Q Ali, Analyzed the Data: I Jan, Contributed reagents/ materials/ analysis tools: M Erkan, Wrote the paper: Q Ali.

\section{Acknowledgement}

The authors are thankful to Mr. Muhammad Ali (Department of Horticulture, University of Swabi), Dr. Abdul Ghafoor (PSO Plant Genetic Resources Institute, NARC), and Dr. Asif Javaid (SSO Plant Genetic Resources Institute, NARC) for their kind guidance throughout this research work.

\section{References}

1. Peralta IE \& Spooner DM (2000). Granule bound starch synthase (GBSSI) gene phylogeny of wild tomatoes (Solanum L. section Lycopersicon [Mill.] Wettst. subsection Lycopersicon). Am J of Bot 88(10): 1888-1902

2. Hartz TK \& Miyao G (1997). Processing tomato production in California, University of California. Division of Agriculture and Natural Resources Publications 7228.

3. Lobell DB, Cahill KN \& Field CB (2007). Historical effects of temperature and precipitation on California crop yields. Climate Change 81: 187-203
4. Norman JC (1992). Tropical vegetable crops. Arthur H Stockwell Ltd United Kingdom pp. 252.

5. Grandillo S, Ku HM \& Tanksley SD (1999). Identifying the loci responsible for natural variation in fruit size and shape in tomato. Theor Appl Genet 99(6): 978-987

6. Munos S, Ranc N, Botton E, Berard A, Rolland S, Duffe P, Carretero Y, Le Pasllier MC, Delalande C, Bouzayen M, Brunel D \& Causse M (2011). Increase in tomato locule number is controlled by two single-nucleotide polymorphisms located near WUSCHEL. Plant Physiol 156(4): 2244-2254

7. Khan TN, Jeelani G, Tariq S, Mahmood $T$ \& Hussain SI (2011). Effect of different concentrations of rooting hormones on growth of tomato cuttings (Solanum esculentus L.). J Agric Res 49(2): 241-247.

8. Colombani VS, Causse M, Langlois D, Philouze J \& Buret M (2001). Genetic analysis of organoleptic quality in fresh market tomato. 1. Mapping QTLs for physical and chemical traits. Theor Appl Genet 102(2): 259-272

9. Schuch W \& Bird C (1994). Improving tomato fruit quality using bioscience. Acta Hortic 376: 75-80

10. AVRDC report (2003). Studies on African eggplant 159-176

11. Dieleman JA \& Heuvelink E (1992). Factors affecting the number of leaves preceding the first inflorescence in the tomato. J Hortic Sci 67(1): 1-10

12. Georgiady MS, Whitkus RW \& Lord EM (2002). Genetic analysis of traits distinguishing outcrossing and selfpollinating forms of currant tomato, Lycopersicon pimpinellifolium (Jusl.) Mill. Genetics 161(1): 333-344

13. Olsson K \& Agren J (2002). Latitudinal population differentiation in phenology, 
life history and flower morphology in the perennial herb Lythrum salicaria. $J$ Evolution Biol 15(6): 983-996

14. Ara A, Narayan R, Ahmed N \& Khan SH (2009). Genetic variability and selection parameters for yield and quality attributes in tomato. Indian $J$ Hortic 66(1): 73-78

15. Tiwari JK \& Upadhyay D (2011). Correlation and path-coefficient studies in tomato (Lycopersicon esculentum Mill.). Res J Agric Sci 2(1): 63-68

16. Souza LM, Melo PCT, Luders RR \& Melo AMT (2012). Correlations between yield and fruit quality characteristics of fresh market tomatoes. Hortic Bras 30: 627-631

17. Pyke GH (1981). Effects of inflorescence height and number of flowers per inflorescence on fruit set in waratahs (Telopea speciosissima). Aust J Bot 29(4): 419-424

18. Nagariya NK, Bhardwaj R, Sharma N, Mukherjee S \& Umesh (2015). Correlation and path analysis in tomato, Solanum lycopersicon L. Int J Farm Sci 5(4): 111-117. 